\title{
Morphology of Hyphae in Leaf Tissues Infected with Java Corn Downy Mildew Fungus, Peronosclerospora maydis, in Relation to Sporulation Ability
}

\author{
Tadaoki INABA*, Toshihiko Hino* and Toshihiro KAJIWARA** \\ 稲葉忠興*・日野稔彦*・暒原敏宏**：トゥモロコシへと病䍜病葉中の \\ 菌采の形態と分生胞子形成能との関係
}

\begin{abstract}
Java corn downy mildew fungus, Peronosclerospara maydis (Racib.) C. G. Shaw [Sclerospora maydis (Racib.) Butl.], was inoculated to seedlings of corn, Zea mays L., at the 2.5-leaf stage and incubated at $25 \mathrm{C}-20 \mathrm{C}$ (daytime-night, $12 \mathrm{hr}$ each) for 27 days. Systemic symptoms appeared on the 6 th-10th leaves of the plant thus treated. For anatomical study, the leaves used were the 8 th, 9 th and 10th leaves which were at the developing stage and the 11th leaf which had not emerged out of leaf whorl and showed inconspicuous symptoms. As for the 8th-10th leaves, samples were taken from sporulating area, non-sporulating area on lesion and border area between these 2 areas. As for the 11th leaf, no conidia were formed on the whole area and the tip part was sampled. Observations made after sectioning the samples embedded in paraffin revealed the presence of 3 kinds of hypha types, i. e., "crooked type", "slender type" and "intermediate type". In the samples taken from the leaf which had not emerged and also from the non-sporulating area, most of hyphae observed were of the slender type, intermingled with a few hyphae of the intermediate type, whereas no crooked type hyphae were found. In the sporulating area, however, most of the hyphae observed were of the crooked type, intermingled with a few hyphae of the intermediate type and very few of the slender type. In the border between these 2 areas, crooked and intermediate type hyphae were mostly observed with a few hyphae of the slender type. From these observations, it was concluded that the hyphae in leaf tissues seem to be of the slender type in non-sporulating areas located in the basal part of leaves at the developing stage as well in non-emerged leaves. These hyphae gradually change to the intermediate type and the crooked type along with the leaf development. After assuming the crooked type, the hyphae seem to be able to produce conidia.
\end{abstract}

(Received December 15, 1979)

\section{Introduction}

Java corn downy mildew disease caused by Peronosclerospora maydis (Racib.) C. G. Shaw ${ }^{4)}$ [Sclerospora maydis (Racib.) But1.] is one of the corn downy mildew diseases and is distributed only in Indonesia. This important disease is not seed-borne and oospores have not been found ${ }^{3}$. The disease dissemination is considered to depend on conidium dispersion ${ }^{3}$.

* National Institute of Agricultural Sciences, Yatabe, Tsukuba, Ibaraki 305, Japan 農業技術研 究所

** Present address: Tropical Agriculture Research Center, Yatabe, Tsukuba, Ibaraki 305, Japan

熱帯農業研究センター 
Two kinds of hypha types have been reported in leaf tissues infected with $P$. maydis ${ }^{3,5}$ and $P$. philippinensis ${ }^{6)}$. The function of these types of hyphae, especially in relation to sporulation ability, however, has not been investigated so far. In a previous paper ${ }^{2}$, the sporulation ability was found to be closely related to host tissue growth, and such ability on a site of diseased leaf appeared after a certain period of time following the emergence of the site of leaf.

The present report deals with the relationship between sporulation ability of the diseased leaves and morphology of hyphae in leaf tissues, as seen in paraffin sections of various parts of the diseased leaves.

\section{Materials and Methods}

Materials and methods which are not described below are the same as those reported in the previous paper ${ }^{2}$, i. e., fungus used, plant cultivation and inoculation methods, test for determination of sporulating area, etc.

Conditions of inoculated plant. Java corn downy mildew fungus, Peronosclerospora maydis (Racib.) C. G. Shaw, was inoculated to seedlings of corn variety Golden Cross Bantam, Zea mays L., at the 2.5-leaf stage. The inoculated plants were incubated at $25 \mathrm{C}-20 \mathrm{C}$ (daytime-night, $12 \mathrm{hr}$ each) in growth cabinet under natural light condition for 27 days. Systemic symptoms appeared on the leaves located above the 6th leaf, as shown in Figure 1. The 6th and 7th leaves which had already developed showed "half-leaf symptoms"1) and the 8th to 10th leaves which were at the developing stage showed "full systemic symptoms"1). These leaves detached from the plants were incubated at $20 \mathrm{C}$ in a dark moist chamber for $20 \mathrm{hr}$. Conidia were formed over the whole lesion surface of the 6th leaf, and they were formed on almost all the lesion surface of the 7th leaf, except for a narrow area in the basal part. As for the 8 th to 10 th leaves, conidia were formed in the upper part of leaves, and the basal parts where conidia were not formed became wider as the leaf order advanced. On the 11 th leaf which had not emerged out of leaf whorl, conidia were not formed in any parts, and symptoms were inconspicuous.

Anatomical study. Leaf pieces used for anatomical study were collected from 3 different areas located on each of the 8 th, 9 th and 10th leaves, and also from the tip of the 11th leaf, as shown in Figure 1. The 3 different areas on the 8th, 9th and 10th leaves consisted of 1) sporulating area, 2) non-sporulating area, and 3) border area between both areas. From each area, $10-20$ leaf pieces $(3 \times 5 \mathrm{~mm}$ in size) were sampled. As for the 11th leaf which was not emerged and did not show conidium formation, 10 leaf pieces ( $3 \mathrm{~mm}$ in length) were sampled from the tip. They were fixed in FAA solution (formalin : acetic acid : $50 \%$ ethanol $=6.5: 2.5: 91$ in volume), embedded in paraffin after dehydration through ethanol-n-butanol series. Sections, $30-35 \mu \mathrm{m}$ in thickness, were stained with Flemming's triple staining series (safranin : gentian violet : orange G). Microscopic observations were catried out on 60-90 sections for each leaf piece, i. e., more than 600 1,200 sections for each area on a leaf.

\section{Results}

Throughout the observation of sections, the hyphae of the fungus in diseased leaf tis- 
sues could be grouped morphologically into 3 types, which were designated as "crooked type", "slender type" and "intermediate type". Their morphological characteristics were as follows: "Crooked type" hyphae were crooked, gnarled, lobed and clustered in shape. "Slender type" hyphae were slender and thread-like. "Intermediate type" hyphae showed a shape intermediate between crooked and slender types.

As to the 8 th, 9th and 10th leaves, which were at the developing stage, 3 different areas were examined on each leaf, i. e., sporulating area, non-sporulating area on lesion, and border area between these 2 areas, as shown in Figure 1. In the sporulating areas on all those 3 leaves, most of the hyphae were found to be of the crooked type (P1. I $5,7,8$. P1.II 15, 16. P1. III 25-28). Intermediate type hyphae were sometimes observed (P1.I 5,7. P1.III 26), but slender type ones were scarce (P1.I 6 . P1.II 16. P1.III 26). In the border area between sporulating and nonsporulating areas on lesion, crooked and intermediate type hyphae were mostly observed (P1.I 9-12. P1.II 17-20. P1.III 29-32). Slender type hyphae were scarce, like in the sporulating area (P1.I 10. P1.II 17, 19. P1.III 30). In the non-sporulating area, most or the hyphae observed were of the slender type (P1.II 13, 21,22. P1.III 33-35), and intermediate type hyphae were sometimes noted (P1.II 14, 23, 24. P1. III 33, 36). No hyphae of the crooked type were found unlike in the case of the sporulating area.

Hyphae in tissues of the 11th leaf which had not emerged out of leaf whorl were mostly of the slender type (P1.I 1-4). Intermediate type

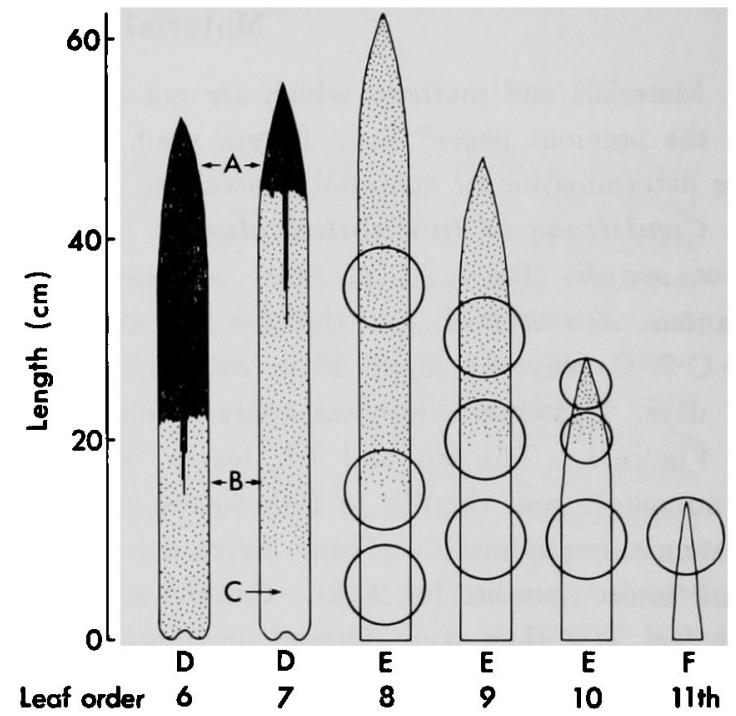

Fig. 1. Symptoms and sampling sites on the leaves of plant tested. Circles in the figure: Sampling sites. A : No symptom and no sporulation. B: Sporulating area on lesion. $\mathrm{C}$ : Non-sporulating area on lesion. D : Already developed leaf. E: Developing leaf. F: Non-emerged leaf out of leaf whorl.

Table 1. Distribution of 3 kinds of hypha types in different areas of diseased leaves

\begin{tabular}{|c|c|c|c|}
\hline \multirow{2}{*}{ Leaf and site in lesion } & \multicolumn{3}{|c|}{ Frequency of observation of hypha types ${ }^{2}$} \\
\hline & Crooked type & Intermediate type & Slender type \\
\hline \multicolumn{4}{|l|}{8 th, 9th and 10th leaves } \\
\hline Sporulating area & WW & $H$ & + \\
\hline Border area & 世 & 曲 & + \\
\hline Non-sporulating area & - & H & HWH \\
\hline 11th leaf (not emerged) & - & + & 十H世 \\
\hline
\end{tabular}

a) - : not observed, + : scarcely, $\#$ : sometimes, less than $1 / 10$ frequency. $\#$ : often, less than $1 / 2$. 曲: very often, more than $1 / 2, H$ : extremely often, more than $9 / 10$. 
hyphae were scarcely noted.

Crooked and intermediate type hyphae frequently branched and slender type hyphae sometimes branched along host cell walls. Some of the slender type hyphae were poorly stained, suggesting that they might be empty (P1.I 2). In some sections, contacts among different types of hyphae were observed, i. e., among crooked, intermediate and slender types (P1.II 17), between crooked and intermediate types (P1.I 11. P1.II 20), and between intermediate and slender types (P1.III 33).

Appearance frequency of 3 kinds of hypha types in each area is summarized in Table 1 , as a result of the observation of 1,500-2,000 fields in 500-600 sections in each area under the microscope at a magnification of $\times 400$. In the 8th, 9th and 10th leaves which were at the developing stage, most of the hyphae observed were of the crooked type in the sporulating area, and of the slender type in the non-sporulating area. In the border area between these 2 areas, crooked and intermediate type hyphae were mostly observed and the latter were more frequently seen than the former. In the case of the 11th leaf which had not emerged out of leaf whorl, most of the hyphae observed were of the slender type, like in the case of the non-sporulating area of the developing leaves. It was very interesting to note that crooked type hyphae could not be found at the site where conidia were not formed.

\section{Discussion}

In tissues of leaves infected with corn downy mildew diseases, 2 kinds of hypha types have been reported on Peronosclerospora maydis by Semangoen ${ }^{32}$ and Sudjadi et al. ${ }^{5)}$ and on $P$. philippinensis by Weston ${ }^{6}$, though the function of these 2 types of hyphae has not been clarified. In one of these types, hyphae ware described as crooked ${ }^{5,6)}$, clustered ${ }^{3,5}$, lobed $^{3,5,6)}$, contorted ${ }^{6)}$, gnarled ${ }^{6)}$, irregular ${ }^{5)}$ and irregularly branched ${ }^{3,6)}$. Whereas in the other type hyphae were described as slender ${ }^{5,6)}$, thread-like ${ }^{5)}$, long ${ }^{6)}$, straight ${ }^{3)}$, cylindrical $^{3)}$, sparsely branched ${ }^{3,5)}$ and occasionally branching( ${ }^{6)}$.

In the present paper, the terms "crooked type" and "slender type" were used to describe the hypha types and these were in agreement with the former and the latter types reported in the literature. During the observation, an intermediate type between crooked slender type, was frequently encountered by the writers. Therefore, the term "intermediate type" is being used in the present paper.

In the leaf which had not emerged yet and also in the non-sporulating area of developing leaf, most of the hyphae observed were of the slender type, intermingled with a few hyphae of the intermediate type, whereas no crooked type hyphae were found. In the sporulating area, however, most of the hyphae observed were of the crooked type, intermingled with a few hyphae of the intermediate type whereas slender type hyphae were scarcely noted. In the border area between the two areas mentioned above, crooked and intermediate type hyphae were mostly observed with a few hyphae of the slender type.

Hyphae distributed in leaf primordium ${ }^{5)}$ stretch into leaf tissues with the elongation of the leaf. At the initial stage of leaf elongation inside leaf whorl, hyphae are slender and thread-like in narrow intercellular spaces of host tissues. For a certain period of time after leaf emergence out of leaf whorl, the hyphae remain slender. Subsequently, they gradually change to the crooked type with an intermediate stage parallel to the morphological 
development of host leaf tissues, in which intercellular spaces of host tissues become wide enough for the hyphae to assume a crooked shape. After becoming crooked in developed leaf tissues, the hyphae seem to be able to produce conidia.

In the previous paper ${ }^{2)}$, sporulation ability on a site of leaf was found to appear after a certain period of time following the emergence of the site of leaf out of leaf whorl. This phenomenon can be explained on the basis of the results of the present observation demonstrating that sporulation ability of hyphae in leaf tissues appears after hyphae undergo a morphological change from the slender to the crooked type.

\section{Literature cited}

1. Cohen, Y. and Sherman, Y. (1977). Phytopathology 67: 515-521.

2. Inaba, T., Hino, T. and Kajiwara, T. (1980). Ann. Phytopath. Soc. Japan 46: 126-131.

3. Semangoen, H. (1970). Indian Phytopath. 23: 307-320.

4. Shaw, C. G. (1978). Mycologia 70: 594-603.

5. Sudjadi, M., Inaba, T. and Kajiwara, T. (1978). Ann. Phytopath. Soc. Japan 44: 142-150.

6. Weston, W. H., Jr. (1920). J. Agr. Res. 19: 97-122.

\section{和 文 摘 要}

\section{トゥモロコシペと病罹病葉中の菌糸の形態と 分生胞子形成能との関係}

\section{稲葉忠興・日野稔彦・暒原敏宏}

トゥモロコシベと病菌の分生胞子は，前報で報告したように，展開直後および展開途上の罹病葉では葉先 側に形成され，葉基部側には形成されない。しかし，日時が释過すると葉基部側にる形成されるようになる。 ベと病菌を2.5葉期のトウモロュシに接種し，病徽が現われた第 $8 \cdot 9 \cdot 10$ 葉の胞子を形成する部分，胞子 を形成しない部分，雨者の境界部分から葉片を採取し，また，未抽出葉の第11葉からも葉片を採取した。連 続ハラフィン切片を作って観察した結果，葉組織中の菌系の形態は 3 種類に分けることができた。すなから， じゅず玉状菌系，釆状菌系，両者の中間型の菌糸である。胞子を形成する部分では，“主ず状菌糸が大多 数を占め，中間型菌系る認められ，糸状菌釆は僅かであった。胞子を形成しない部分扰よび未抽出葉では， 手状菌系が大多数であり，中間型菌系も認められたが，しゅず玉状菌禾は全然認められなかった。胞子を形 成する部分と形成しない部分の境界部分では，じず玉状菌系と中間型菌系とが大多数を占め，系状菌系る 認められた。以上の結果から，べと病菌の菌系は抽出中および展開直後の葉組織内に打いては系状であり， 日時が経過すると中間型菌系となり，その後じず王状菌采になるるのと思われる。またししゅす王状菌糸 になったのらに分生胞子形成能をむつようになるものと思われる。 


\section{Explanation of Plates}

Throughout the plates, photographs of left 2 rows are longitudinal sections of diseased leaves $(\times 480)$ and those of right row are cross sections $(\times 420)$. Abbreviations in the photographs are $C$ : crooked type hyphae, I: intermediate type hyphae and 5 : slender type hyphae.

\section{Plate I.}

1- 4 Hyphae in tissue of the 11th leaf which had not emerged out of leaf whorl.

5-12 Hyphae in tissue of the 10th leaf. 5-8: sporulating area, and 9-12: border area.

\section{Plate II.}

13-14 Hyphae in tissue of the 10th leaf. Non-sporulating area.

15-24 Hyphae in tissue of the 9th leaf. 15-16: sporulating area, 17-20: border area, and 21-24: non-sporulating area.

Plate III.

25-36 Hyphae in tissue of the 8th leaf. 25-28: sporulating area, 29-32: border area, and 33-36: non-sporulating area. 


\section{Plate I}

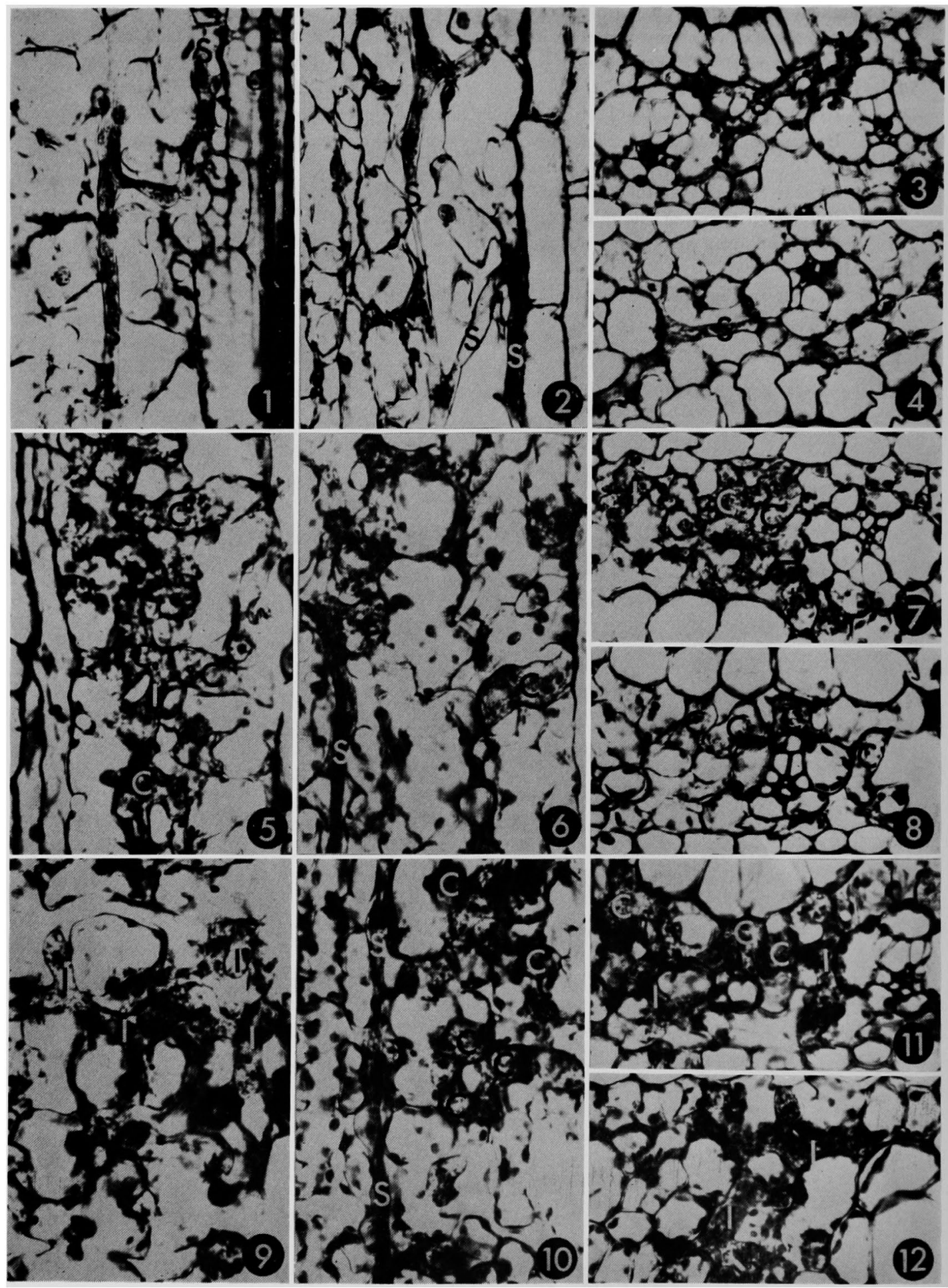




\section{Plate II}

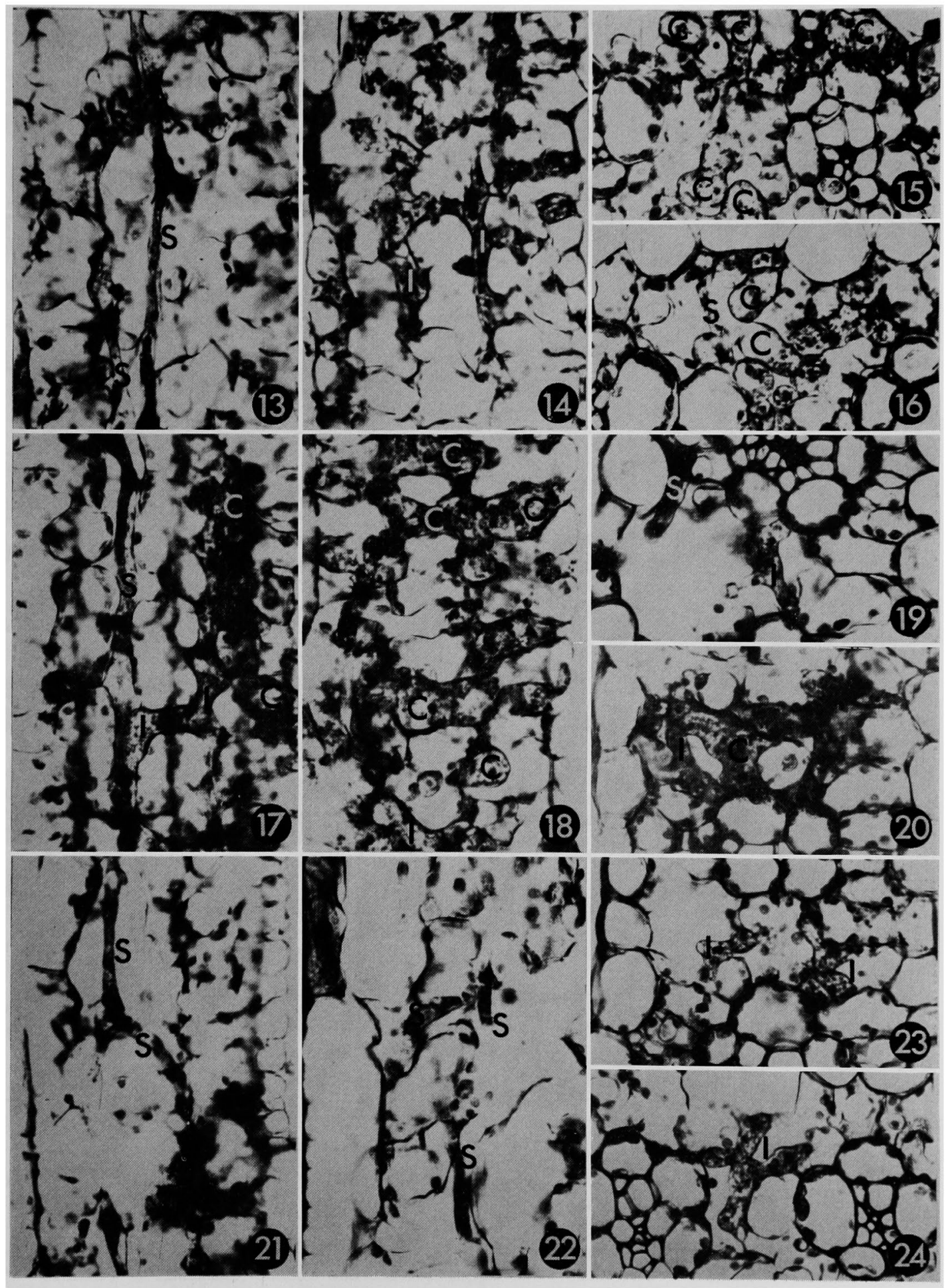




\section{Plate III}

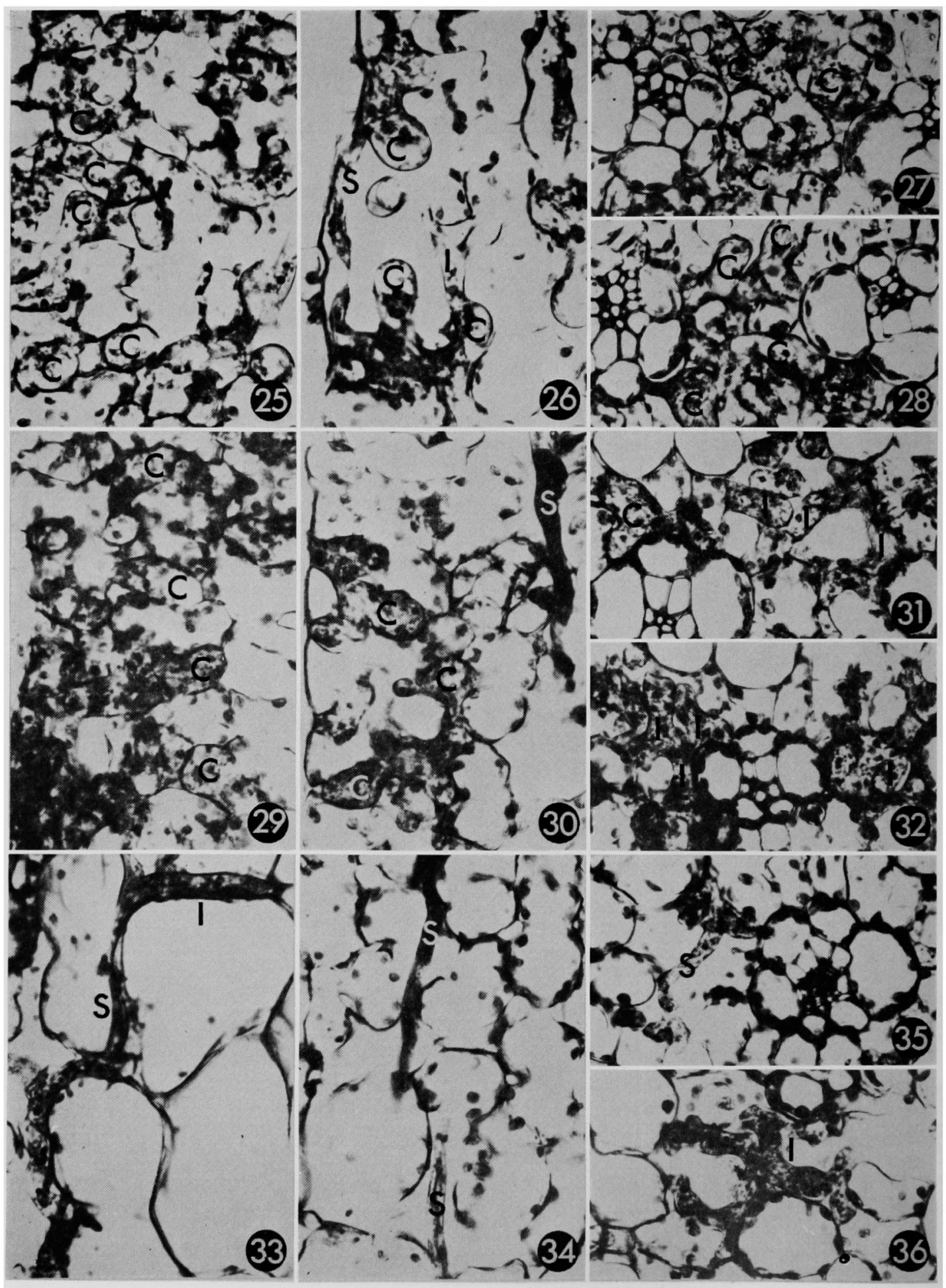

